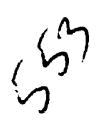 \\ jA. 642}

Reprinted from Crop Sience

Vol. 28, No. 1

\title{
Further Studies on Genetics of Nonnodulation in Peanut
}

\author{
M. Dutta and L. J. Reddy*
}

\begin{abstract}
In the peanut (Arachis hypogaea $\mathrm{L}$.) nonnodulation has been reported to be controlled by both duplicate recessive genes and a single recessive gene. In the present study genetics of peanut nonnodulation was investigated in four crosses from data on $F_{2}$ populations and $F_{3}$ progenies from nonnodulating $F_{2}$ plants. The $F_{2}$ data of all the four crosses studied showed a better fit for a trigenic ratio of 61 nodulating to three nonnodulating plants compared to the previously reported duplicate digenic ratio of 15 nodulating to one nonnodulating $F_{2}$ plants. Further, the segregation of $F_{3}$ progenies from nonnodulating $F_{2}$ plants indicated the inadequacy of the duplicate factor model. A new genetic model involving three genes in the inheritance of nonnodulation is proposed. Two genes produce nodulation while the third gene inhibits nodulation only when it is dominant and the former two genes are in recessive homozygous condition. By assuming differential heterozygosity at the three loci of the parents involved in various crosses, the duplicate factor and monogenic ratios reported by previous workers on nonnodulation could be explained by the new model. Although the occurrence or non-occurrence of nodules is governed by a few major genes, the intensity of nodulation appears to be controlled quantitatively.
\end{abstract}

Additional index words: Groundnut, Arachis hypogaea L., Trigenic inheritance.
Deanut is nodulated by the "cowpea miscellany group" of Bradyrhizobium and typical nodules are found on its roots. The first report of nonnodulation in peanut was made by Gorbet and Burton (3) for the $F_{3}$ progenies of a cross, 487A-4-1-2 $\times$ PI 262090 . They suggested that because nonnodulating $F_{5}$ selections produced nodulating genotypes, nonnodulation was probably not controlled by a single recessive gene. Nigam et al. (5) observed nonnodulation in the $F_{2}$ generation of the cross NC $17 \times$ PI 259747. Based upon data from large $F_{2}$ and $F_{3}$ populations they concluded that nonnodulation was conditioned by duplicate recessive genes. Dashiell and Gorbet (2), suggested a modified ratio of 14 nodulating to one few to one nonnodulating. Subsequently, nonnodulation was detected in various generations of hybrids among 12

M. Dutta and L.J. Reddy, Legumes Program, Internat. Crops Res. Inst. for the Semi-Arid Tropics, Patancheru, A.P. 502 324, India. ICRISAT Journal Article no. 642. "Corresponding author. Received 2 Dec. 1986.

Published in Crop Sci. 28:60-62 (1988). 
cross combinations (4). Recently, Branch et al. (1) tested the allelic relationships among six nonnodulating lines derived from earlier reported studies $(2,3,6)$ and concluded that similar recessive alleles were probably operating in all the lines. In the present paper, we report on the unsuitability of the duplicate recessive model to explain nonnodulation in some crosses of peanut and suggest a new genetic model.

\section{MATERIALS AND METHODS}

Four crosses involving PI 109839 used as the female parent were chosen for the present study because they showed segregation for nodulation in the $F_{2}$ generation. Four lines, PI 259769, PI 341879, PI 405132, and PI 259747 were used as male parents. The $F_{2}$ populations of the four crosses were grown in the 1984 rainy season at the ICRISAT Center during June to October months in 10-m-long rows, spaced 60 $\mathrm{cm}$ apart, with an intra-row spacing of $15 \mathrm{~cm}$. The $F_{2}$ plot sizes ranged from 8 to 16 rows and the populations observed for nodulation ranged from 316 to $556 \mathrm{~F}_{2}$ plants per cross. Both parents were grown for comparison in double rows on either side flanking their respective progenies. The fields in which plants from these crosses were grown contained abundant native Bradyrhizobium populations as revealed by the history of crops grown in previous seasons, and the parents always nodulated normally thus precluding the possibility of escapes. Crosses showing segregation for nonnodulation were easily recognized because of yellow foliage on nonnodulating plants from the seedling stage onwards. At harvest all $F_{2}$ plants of each cross were individually uprooted and maximum root length was collected to evaluate nodulation. Plants with one or more nodules were classified as nodulating.

The $F_{3}$ progeny rows of all the nonnodulating $F_{2}$ plants were grown in the 1984-1985 postrainy season at ICRISAT Center during November to April months and nodulation was recorded. The data on $F_{2}$ generation and $F_{3}$ progenies of nonnodulating $F_{2}$ plants were subjected to chi-square analyses. As there were few plants in the $F_{3}$ generation Yates' (7) correction for continuity was applied.

\section{RESULTS AND DISCUSSION}

Parental and $F_{1}$ generation plants showed normal nodulations with nodule numbers ranging from 100 to 600 in all four crosses. The $F_{2}$ generation of all the four crosses showed a very good fit to 61 nodulating to three nonnodulating plants (Table 1) indicating an

Table 1. Goodneas-of-fit teats for ratios of 61 nodulating to three nonsodulating types and for dupliente factor ratio of 15 sodulating to ose noenodulating amones $F_{2}$ plante in four peannt

\begin{tabular}{|c|c|c|c|c|c|c|}
\hline \multirow{3}{*}{$\frac{\text { Croes }}{\text { PI } 109839 \times \text { PI } 269839}$} & \multicolumn{3}{|c|}{ Number of $F$, plants } & \multirow{2}{*}{\multicolumn{2}{|c|}{$\begin{array}{l}x^{2} \text { for } 61: 3 \\
\text { and } 15: 1 \\
\text { ratios }\end{array}$}} & \multirow{3}{*}{$\frac{P \text { value }}{0.10-0.05}$} \\
\hline & \multirow{2}{*}{$\frac{\begin{array}{c}\text { Nodu- } \\
\text { lating }\end{array}}{308}$} & \multirow{2}{*}{$\frac{\begin{array}{c}\text { Nonnodu- } \\
\text { lating }\end{array}}{B}$} & df & & & \\
\hline & & & 1 & $\begin{array}{l}3.287 \\
7.460\end{array}$ & $\begin{array}{l}(61: 3) \\
(15: 1)\end{array}$ & \\
\hline PI $108889 \times$ PI 341879 & 495 & 27 & 1 & $\begin{array}{l}0.276 \\
1.034\end{array}$ & $\begin{array}{l}\text { (61:3) } \\
(16: 1)\end{array}$ & $\begin{array}{l}0.70-0.60 \\
0.40-0.80\end{array}$ \\
\hline PI $100859 \times$ PI 405132 & 526 & 30 & 1 & $\begin{array}{l}0.624 \\
0.693\end{array}$ & $\begin{array}{l}(61: 3) \\
(16: 1)\end{array}$ & $\begin{array}{l}0.50-0.40 \\
0.50-0.40\end{array}$ \\
\hline PI $109899 \times$ PI 259747 & 319 & 18 & 1 & $\begin{array}{l}0.322 \\
0.475\end{array}$ & $\begin{array}{l}(61: 3) \\
(15: 1)\end{array}$ & $\begin{array}{l}0.60-0.50 \\
0.50-0.40\end{array}$ \\
\hline Poolad & 1648 & 83 & 1 & $\begin{array}{l}0.044 \\
6.254\end{array}$ & $\begin{array}{l}7(61: 3) \\
9(16: 1)\end{array}$ & $\begin{array}{l}0.85-0.80 \\
0.02-0.01\end{array}$ \\
\hline Heterogeneity & & & 8 & $\begin{array}{l}4.478 \\
3.397\end{array}$ & $\begin{array}{l}\text { (61:3) } \\
(16: 1)\end{array}$ & $\begin{array}{l}0.80-0.20 \\
0.40-0.30\end{array}$ \\
\hline
\end{tabular}

involvement of three genes. Three crosses, PI 109839 $\times$ PI 341879, PI $109839 \times$ PI 405132, and PI 109839 $X$ PI 259747, also showed a satisfactory fit to a digenic 15:1 ratio. Although heterogeneity among the four crosses was non-significant for both ratios tested, the deviation of total $\chi^{2}$ from a 15:1 ratio is highly significant. Thus $61: 3$ ratio appears to be a better fit for the present set of crosses. Also, the duplicate recessive model cannot be accepted because nonnodulating plants which should breed true showed segregation in the $F_{3}$. Because some of the nonnodulating plants segregated into nodulating and nonnodulating types, we may assume that at least one gene influencing nodulation must be in the heterozygous condition in these genotypes. A trigenic model of inheritance with two genes for nodulation and one gene for nodule inhibition is the least complex model for explaining the ratios. To produce a ratio of 61 nodulating to three nonnodulating plants in $F_{2}$ generation, one of the parents should be triple recessive $\left(n_{1} n_{1} n_{2} n_{2} n_{3} n_{3}\right)$ while the second parent should be triple dominant $\left(N_{1} N_{1}\right.$ $N_{2} N_{2} N_{3} N_{3}$ ) or the parents should have any other constitution that would produce a $F_{1}$ heterozygous for all the three loci. The nonnodulating plants would then have either of the following genetic constitutions: $n_{1}$ $n_{1} n_{2} n_{2} N_{3} N_{3}$ or $n_{1} n_{1} n_{2} n_{2} N_{3} n_{3}$. The first two genes together result in nodulation while the third gene inhibits nodulation only when it is dominant and the other two genes are homozygous recessive. The triple recessive genotype would show normal nodulation, because the nodulation inhibitor in the recessive condition cannot suppress nodulation.

Plants derived from the above two nonnodulating $F_{2}$ genotypes should segregate in the $F_{3}$ into five nonnodulating to one nodulating type, and the family segregation should follow a two segregating to one nonsegregating ratio. While the $F_{3}$ plant population derived from the nonnodulating $F_{2}$ plants fitted well with the 5:1 ratio (Table 2), the family ratio did not fit the expected $2: 1$ ratio. It may be noted that due to the shrivelled nature of seeds (poor seed reserves), and possibly dormancy, the nonnodulating progeny rows did not provide an ideal plant stand. Thus, observation on the segregation within an individual family may be misleading because the occurrence or non-occurrence of a single nodulating plant can determine the segregating or non-segregating character of a family. But when families are pooled, ratios of plants are expected to provide a better fit because of their large numbers.

The $F_{2}$ data of three other crosses from our lab re-

Table 2. Clasedification of F, plants for nonnodulating ve. sodulating phenotypes (5:1) in four peanut croceses.

\begin{tabular}{|c|c|c|c|c|c|c|}
\hline \multirow[b]{2}{*}{ Croveces } & \multirow[b]{2}{*}{$\underset{\text { familieg }}{F_{2}}$} & \multicolumn{2}{|c|}{ Plante } & \multirow[b]{2}{*}{ df } & \multirow[b]{2}{*}{$x^{2 t}$} & \multirow[b]{2}{*}{$P$ value } \\
\hline & & $\begin{array}{l}\text { Nonnodu- } \\
\text { lating }\end{array}$ & $\begin{array}{l}\text { Notu- } \\
\text { lating }\end{array}$ & & & \\
\hline $\begin{array}{l}\text { PI } 100399 \times \text { PI } 259639 \\
\text { PI } 100989 \times \text { PI } 341879 \\
\text { PI } 100389 \times \text { PI } 405130 \\
\text { PI } 100389 \times \text { PI } 269747\end{array}$ & $\begin{array}{r}6 \\
22 \\
24 \\
15\end{array}$ & $\begin{array}{r}6 \\
81 \\
101 \\
43\end{array}$ & $\begin{array}{l}4 \\
24 \\
18 \\
13\end{array}$ & $\begin{array}{l}1 \\
1 \\
1 \\
1\end{array}$ & $\begin{array}{l}1.9804 \\
2.4138 \\
0.1099 \\
1.2871\end{array}$ & $\begin{array}{l}0.25-0.10 \\
0.25-0.10 \\
0.75-0.70 \\
0.30-0.26\end{array}$ \\
\hline $\begin{array}{l}\text { Pooled } \\
\text { Heterogeneity }\end{array}$ & & 231 & 69 & $\begin{array}{l}1 \\
3\end{array}$ & $\begin{array}{l}2.5453 \\
2.1959\end{array}$ & $\begin{array}{l}0.25-0.10 \\
0.55-0.60\end{array}$ \\
\hline
\end{tabular}

t With Yeter' corruction. 
vealed that in two crosses, NC-Fla $14 \times$ NC Ac 17090 $\left(\chi^{2}=4.441 ; P>0.02\right)$ and NC $17 \times$ NC Ac 17090 $\left(\chi^{2}=0.201 ; P>0.70\right)$ the fit for the presently proposed $61: 3$ ratio was satisfactory, whereas the cross, NC 17 $\times$ EC $76446(242)$ did not show a good fit to this ratio.

Gorbet and Burton (3) pointed out that nonnodulation was probably not governed by a single recessive gene. Their suggestion came from the fact that a few of the nonnodulating $F_{\text {s }}$ selections showed segregation in the next generation. Nigam et al. (9) reported the digenic control of nonnodulation in a cross of NC 17 $X$ PI 259747. However, many of the nonnodulating genotypes segregated into nodulating and nonnodulating types later (P.T.C. Nambiar, personal communication) indicating the unsuitability of the duplicate recessive model. Dashiell and Gorbet (2) supported the duplicate factor model for nonnodulation. However, for another cross they reported a three nodulating to one nonnodulating ratio indicating that nonnodulation was controlled by a single recessive gene.

The allelism test reported by Branch et al. (1) was carried out in six nonnodulating lines of which the cross PI $109839 \times$ PI 341879 was common to our study. The cross UF 487 A-4-1-2 X PI 262090 was originally reported by Gorbet and Burton (3) and the cross NC $17 \times$ PI 259747 was used by Nigam et al. $(5,6)$ to derive the duplicate factor model. Based on $F_{\text {, nonnodulation it was concluded that similar alleles }}$ were responsible for nonnodulation in all these six crosses. Thus, a genetic ratio similar to that found in our study is expected to occur if the same number of genes controls nonnodulation in these crosses. But data reported by Nigam et al. $(5,6)$ did not fit our genetic model nor did the cross NC $17 \times$ EC 76446(242). It is likely that different genetic mechanisms for nonnodulation are operative in these two crosses and possibly also in the two crosses reported by Dashiell and Gorbet (2). Alternatively, parents of these crosses may have different heterozygosity with respect to these three loci resulting in different $F_{2}$ ratios. If the parental constitution is such that the resulting hybrid is heterozygous for the first two loci and homozygous dominant for the third locus (e.g. $N_{1} N_{1} n_{2} n_{2} N_{3} N_{3} / n_{1} n_{1} N_{2} N_{2}$ $N_{3} N_{3}$ ) then the segregation ratio in $\mathrm{F}_{2}$ will be 15 nodulating to one nonnodulating. Similarly if the parental constitution results in a hybrid which is homozy- gous recessive for either of the first two loci and heterozygous for the other and homozygous dominant for the third locus (e.g., $n_{1} n_{1} N_{2} N_{2} N_{3} N_{3} / n_{1} n_{1} n_{2} n_{2}$ $N_{3} N_{3}$ ) the $\mathrm{F}_{2}$ segregation will follow a ratio of three nodulating to one nonnodulating plants. Thus, the new genetic model satisfactorily explains the observations made by other workers $(2,5)$.

In tetraploid species such as Arachis hypogaea one frequently encounters duplicate factors or more complex inheritance modes for qualitative characters due to redundancy of loci arising from the diploid progenitor species. Hence the nonnodulation trait in peanut can be considered as a qualitative trait governed by a few major genes. On the other hand, considering the complexity of symbiotic association, the occurrence of the "few big" class as reported by Dashiell and Gorbet (2), and the different nodulation patterns observed even within a cultivar, it is probable that the intensity of nodulation is a complexly inherited trait controlled by several minor genes.

\section{ACKNOWLEDGMENTS}

We would like to thank Dr. A. Bandyopadhyay, IARI Regional Station, Hyderabad for his help in the genetic analysis and ICRISAT colleagues, Drs. S.N. Nigam, B.V.S. Reddy, P.T.C. Nambiar, S.L. Dwivedi, and R.W. Gibbons for their helpful comments.

\section{REFERENCES}

1. Branch, W.D., R.O. Hammons, and C.S. Kvien. 1984. Nonnodulating allelism test in Arachis hypogaea (L.), Oleagineux 39:487488.

2. Dashiell, K.E., and D.W. Gorbet. 1982. Genetic analysis of a nonnodulating peanut. Agron. Abstr., ASA, Madison, WI, p. 63.

3. Gorbet, D.W., and J.C. Burton. 1979. A nonnodulating peanut. Crop Sci. 19:727-728.

4. Nambiar, P.T.C., P.J. Dart, S.N. Nigam, and R.W. Gibbons. 1982. Genetic manipulation of nodulation in groundnut. p. 4956 In Graham, P.H. and S.C. Harris (ed.) Biological nitrogen fixation technology for tropical agriculture, CIAT, Cali, Colombia.

5. Nigam, S.N., V. Arunachalam, R.W. Gibbons, A. Bandyopadhyay, and P.T.C. Nambiar. 1980. Genetics of nonnodulation in groundnut (Arachis hypogaea L.). Oleagineaux 35:453-455.

6. ---, P.T.C. Nambiar, S.L. Dwivedi, R.W. Gibbons, and P.J. Dart. 1982. Genetics of nonnodulation in groundnut (Arachis hypogaea L.). Studies with single and mixed Rhizobium strains. Euphytica 31:691-693.

7. Yates, F. 1934. Contingency tables involving small numbers and the $\chi^{2}$ test. J. R. Stat. Soc. Suppl. 1:217-235. 
Indian Journal of Agricultural Sciences 58 (11) : 840-3, November 1988

Inheritance and linkage relationships of qualitative characters in pearlmillet (Pennisetum glaucum)

\author{
S. APPA RAO', MELAK H. MENGESHA' and C. RAJAGOPAL REDDY' \\ International Crops Rescarch Institute for the Semi-Arid Tropics, Patancheru, \\ Andhra Pradesh 502324
}

Received: 18 August 1987

\begin{abstract}
In pearlmillet [Pennisetum glaucum (Linn.) R. Br. emend. Stuntz; syn. $P$. americanum (Linn.) Leeke, P. typhoides (Burm. f.) Stapf \& C. E. Hubb.] reciprocal crosses were made between genetic stocks having contrasting characters, and the mode of inheritance and linkage relationships were determined from the $F_{2}$ segregation data. Purple colour on stems, leaves, bristles and glumes in 'IP 8073' was controlled by a single dominant gene. Purple nodes and auricles were monogenic dominant to green nodes and auricles. Node colour showed complementary gene interaction. The chlorina-virescens mutant was found monogenic recessive to normal. Hairy nodes were monogenic dominant to glabrous nodes, whereas hairy leaf sheaths and blades were monogenic recessive to glabrous leaf sheaths and blades. Bristle length was intermediate in $F_{1}$ and continuous variation in $F_{2}$, indicating the additive action of more than 1 gene. The joint $F_{2}$ segregation data revealed independent assortment of purple with yellow foliage and dense long hairs on leaves.
\end{abstract}

To establish linkage maps in pearlmillet [Pennisetum glaucum (Linn.) R. Br. emend. Stuntz; syn. P. americanum (Linn.) Leeke, $P$. typhoides (Burm. f.) Stapf \& C.E. Hubb.], morphological variants with distinct phenotypic expression are being isolated while evaluating the world collection of its germplasm in India. These morphological variants are purified by selfing and subsequent selection. As information on inheritance and linkage relationships is very limited (Minocha et al., 1980; Koduru and Krishna Ras, 1983), we studied the inheritance of purple plant colour, yellow foliage, hairiness on leaves and nodes, bristle length and linkage relationships among purple colour, yellow foliage and hairiness on leaves.

\section{MATERIALS AND METHODS}

Six different genetic stocks ('IP 8008', 'IP 8056', 'IP 8073', 'IP 8210', 'IP 8056' and 'IP 8214') having contrasting charac-

\footnotetext{
'Botanist, 'Leader, 'Research Associate,
}

ters were used in the study. In 'IP 8073' purple pigment develops on leaf blades, leaf sheaths and internodes, approximately 3 weeks after emergence, and on bristles and glumes within 3 days after ear emergence. It is completely glabrous and has $30 \mathrm{~mm}$-long bristles. As it has the d2 dwarfing gene, it grows to a height of $80 \mathrm{~cm}$ (Appa Rao et al., 1986). 'IP 8288' has yellowish-green foliage that gradually turn light green after flowering owing to a single recessive gene (Appa Rao et al., 1984). It is tall $(232 \mathrm{~cm})$ and has short $(7 \mathrm{~mm})$ bristles. In 'IP 8210' the nodes and auricles are purple, with a ring of dense long hairs on the top nodes. "IP $8214^{\prime}$ has green and glabrous nodes and auricles. 'IP 8056' has dense long hairs on its leaf blades and sheaths, but 'IP $8214^{\prime}$ is glabrous. 'IP 8008' and 'IP 8214' have green nodes.

Crosses were made between genetic stocks with contrasting characters, taking advantage of protogyny (Burton, 1980) during the rainy season of 1983 . The $F_{1} s$ were advanced during the post-rainy 
Indian Journal of Agricultural Sciences 58 (11): 840 3, November 1988

\title{
Inheritance and linkage relationships of qualitative characters in pearlmillet (Pennisetum glaucum)
}

\author{
S. APPA RAO', MELAK H. MENGESHA' and C. RAJAGOPAL REDDY' \\ International Crops Rescarch Institute for the Semi-.Arid Tropics, Patancheru, \\ Andhra Pradesh 502324
}

Received: 18 August 1987

\begin{abstract}
In pearlmillet [Pennisetum glaucum (Linn.) R. Br. emend. Stuntz; syn. $P$, americanum (Linn.) Leeke, P. typhoides (Burm. f.) Stapf \& C. E. Hubb.) reciprocal crosses were made between genetic stocks having contrasting characters, and the mode of inheritance and linkage relationships were determined from the $F_{2}$ segregation data. Purple colour on stems, leaves, bristles and glumes in 'IP 8073' was controlled by a single dominant gene. Purple nodes and auricles were monogenic dominant to green nodes and auricles. Node colour showed complementary gene interaction. The chlorina-virescens mutant was found monogenic recessive to normal. Hairy nodes were monogenic dominant to glabrous nodes, whereas hairy leaf sheaths and blades were monogenic recessive to glabrous leaf sheaths and blades. Bristle length was intermediate in $F_{1}$ and continuous variation in $F_{2}$, indicating the additive action of more than 1 gene. The joint $\mathbf{F}_{1}$ segregation data revealed independent assortment of purple with yollow foliage and dense long hairs on leaves.
\end{abstract}

To establish linkage maps in pearlmillet [Pennisetum glaucum (Linn.) $\mathbf{R}$. Br. emend. Stuntz; syn. P. americanum (Linn.) Leeke, $P$. typhoides (Burm. f.) Stapf \& C.E. Hubb.], morphological variants with distinct phenotypic expression are being isolated while evaluating the world collection of its germplasm in India. These morphological variants are purified by selfing and subsequent selection. As information on inheritance and linkage relationships is very limited (Minocha et al., 1980; Koduru and Krishna Ran, 1983), we studied the inheritance of purple plant colour, yellow foliage, hairiness on leaves and nodes, bristle length and linkage relationships among purple colour, yellow foliage and hairiness on leaves.

\section{MATERIALS AND METHODS}

Six different genetic stocks ('IP 8008', 'IP 8056', 'IP 8073', 'IP 8210', 'IP 8056' and 'IP 8214') having contrasting charac-

\footnotetext{
'Botanist, 'Leader, 'Research Associate,

ters were used in the study. In 'IP 8073' purple pigment develops on leaf blades, leaf sheaths and internodes, approximately 3 weeks after emergence, and on bristles and glumes within 3 days after ear emergence. It is completely glabrous and has $30 \mathrm{~mm}$-long bristles. As it has the d2 dwarfing gene, it grows to a height of $80 \mathrm{~cm}$ (Appa Rao et al., 1986). 'IP 8288' has yellowish-green foliage that gradually turn light green after flowering owing to a single recessive gene (Appa Rao et al., 1984). It is tall $(232 \mathrm{~cm})$ and has short (7 $\mathrm{mm}$ ) bristles. In 'IP 8210' the nodes and aurivles are purple, with a ring of dense long hairs on the top nodes. "IP 8214' has green and glabrous nodes and auricles. 'IP 8056' has dense long hairs on its leaf blades and sheaths, but 'IP 8214 ' is glabrous. 'IP 8008' and 'IP 8214' have green nodes.

Crosses were made between genetic stocks with contrasting characters, taking advantage of protogyny (Burton, 1980) during the rainy season of 1983 . The $F_{1} s$ were advanced during the post-rainy 